the ballet Don Quixote at the Bolshoi (pp. 60-61). These interesting sections are, at least for the specialist in Russian literature and drama, disappointingly brief.

Perhaps one reason is the language barrier, since Miller writes so little about his meetings with writers, and regarding the stage productions he speaks almost exclusively of visual impressions (actor's makeup, physical movement, projected images on screens, etc.). He does make specific references to the language barrier, as when his lady interpreter at the Triangular Pear "simply sat there shaking her head and weeping," only able to say, "Oh, it's so beautiful!" (p. 12). Later, when the Millers, Kataev, and Mrs. Evtushenko encounter an odd character near Pasternak's grave (p. 34), Miller cannot understand what he is saying to Kataev, but Kataev explains that the man was quoting Pushkin. However, in a similar encounter in Tashkent (pp. 31-32) a drunk staggers up to the Millers and mumbles clearly understood criticism of America's race problems. If one assumes that a seedy drunk in the provinces would not be speaking English, Miller here must have had an interpreter-who might well have translated whatever she wished?

In Russia also has some small errors in rendering Russian words in English: Pergevalsky St. for Przhevalsky (p. 90), Graf Hulin for Count Nulin (p. 110), Mezhdu for Mejnun (p. 53), Yacovlena for Yakovlevna (p. 166), and several mistakes on page 162: Savadsky for Zavadsky, Anismovoy-Wulf for AnisimovaWulf, Serafina Birman for Serafima (also p. 42), and S. G. Ranevskaya for Faina Ranevskaya. Aside from these linguistically understandable misprints, the reviewer noted only three errors of content: Vasilievsky Island is referred to as "Ostrovsky Island" (p. 77), the Moscow Soviet Theater is called "Akademichesky Theater" (p. 162), and the Facets Palace in the Moscow Kremlin is said to have been "built in 1491 ... during the reign of Ivan the Terrible [who was born in 1530]" (p. 141).

One of Miller's most perceptive sections deals with the theory and practice of socialist realism (pp. 38-40), where he points out that "there is nothing wrong with Socialist Realism as an aesthetic theory, only provided that the artist is indeed a Socialist Realist." He also calls it "an aesthetic yardstick which frequently is made of rubber and sometimes of oak hard enough to crack any skull."

This quotation, and a number of similar flashes of colorful, poetic language (see also p. 63) enrich a book generally characterized by sober, serious prose. Heterogeneous as it is, Miller and Morath's book provides a fascinating look at the country and people that have so intrigued Westerners, be they Russian-area specialists, writers like Arthur Miller, or the general public.

Steven P. Hill University of Illinois, Urbana

\title{
NATIVE REALM : A SEARCH FOR SELF-DEFINITION. By Czeslaw Milosz. Translated by Catherine S. Leach. Garden City: Doubleday \& Co., 1968. v, 300 pp. $\$ 5.95$.
}

Goethe's saying "Wer den Dichter will verstehen muss nach Dichter Lande gehen" is very true of Milosz, a poet. But a journey to his country is hardly possible. His beloved homeland exists today in history, in poetry, and in the memory of the older generation of its sons rather than in reality. It was old Lithuania, which has been erased from the political map of Europe and whose specific cultural tradition seems to have been broken down under the Soviet occupation. Milosz's book invites us to an imaginative journey to a culture and time that have passed away. 
The large Eastern Polish frontier, which spread from the Baltic coast almost to the Black Sea, supplied to the Polish culture a particularly great number of poets, writers, and national heroes. This fact can be explained only by the intensity of cultural contacts, which has usually been responsible for the blossoming of culture. Lithuanians, Samogitians, Poles, Belorussians, Jews, Tatars, and Armenians lived there together for centuries. A natural point of gravitation for these territories was the kingdom of Poland, which, having been Christianized in the tenth century, joined the European community four hundred years earlier. The gentry culture of the Old Polish Republic assimilated all native nobility and the educated strata of these territories. Later, at the end of the nineteenth century, the rise of nationalism sharply separated these Polonized strata from the masses of the same ethnic origin.

Milosz's essays present in poetic style a sociological insight into the multifold problems of his birthplace. His local patriotism has led him to write very beautifully about the nature of this province and Wilno, the city of his youth. Cities are like women, unhappy when loved by too many different people. This has been the ancient capital for Lithuanians, the northeast bastion of the national culture for Poles, and also the "Jerusalem of the North" for East European Jews.

Milosz's essays comprise an autobiography of a man whose particular background and experiences keep him in the position of a perennial seeker for identity. Of Polish-Lithuanian gentry origin, with a deep sentiment for the Lithuanian folk, he is a Polish-Russian bilinguist by chance; a religious man of solid Catholic training and deep Marxist indoctrination; educated in law but devoted to poetry; snobbish by inclination but democratic by choice; Westernized by educationOriental in certain atavistic attitudes. The autobiographical threads of the book are interwoven with the sociocultural problems of our age: nationalism, Marxism, totalitarianism. The conflicting as well as the correlated aspects of Catholicism and Marxism prevade all his thought. His historicosociological considerations in the chapter "Russia" give deeper insight into that country than many treatments by specialists.

The author has a certain traumatic resentment against the Polish nation, and he confesses it with full honesty. But it has unfortunately caused his one-sided views on the Polish state between the wars and has also led him to repeat some Communist falsehoods concerning the history of the Polish underground movement. It is remarkable that the author, who is so sensitive on moral problems, was unable to see this movement as above all a great moral deed of the nation. The autobiography shows the limitation of his own experience during that time. It is perhaps for this reason that the pages devoted to it are rather pale. Milosz does not understand the difference between patriotism and nationalism. This causes him to divide the Polish nation into two parts: a small but intelligent group of leftists and the repugnant rest of the nation-nationalistic rightists. This is a naive simplification. Before the war nationalistic radicals did a great deal of blustering and were therefore more visible than others (like young radicals in America today) though they were still in the minority.

The book is a new "Confession of a Child of the Century." But this "child" of Eastern Europe has more to say than his predecessor from nineteenth-century France-Alfred de Musset. The beauty of Milosz's style is congenially reflected in C. S. Leach's translation, which brings the author's home country nearer to the Western reader. 